\title{
The Nature of Conyo in Davao City: A Language Inquiry
}

\author{
Albino, Yra C. \\ Bachelor of Arts in English \\ University of Mindanao - Matina Campus \\ Davao City, Philippines \\ yra279@gmail.com
}

\section{Ana Helena R. Lovitos, Ph. D.}

\author{
Romo, Kristine B.
}

Bachelor of Arts in English

University of Mindanao - Matina Campus

Davao City, Philippines

Kristine.romo@yahoo.com

\author{
Adviser, University of Mindanao - Matina Campus \\ Davao City, Philippines \\ Lovitos.phd@gmail.com
}

\begin{abstract}
The main objective of this study is to determine the nature of the new language for the people to be aware how it attempts to influence a man's social and academic life. In attempt to expose the nature of this language, the researchers used qualitative method to explicitly unfold, determine and share this topic. Moreover, during the course of information gathering, the researchers spent time to record random people's conversation who talked in conyo way, in and out of the school. Results reveal that a conyo speech has its own characteristics whenever an individual utters the words. In addition, as a speaker engages in conyo speech, variation occurs in accordance with its different sentence pattern as translating conyo into English. Finally, a student's academic and social life is affected due to some environmental factors.
\end{abstract}

Keywords: nature, language inquiry, Davao Conyo, University of Mindanao, Philippines.

\section{INTRODUCTION}

\subsection{Statement of the Problem}

The main objective of this study is to determine the nature of the new language for the people to be aware how this language attempts to influence a man's social and academic life. This study seeks to answer the following questions:

1. What are the most commonly used conyo terms in Davao?

2. What are the morphosyntactic features of the terms used by conyo in Davao?

3. How do the conyo in Davao affect the students' academic and social activities?

\subsection{Theoretical Framework}

The theory that helped the researchers build the pillar of the study is the theory of Morphosyntax. Morphosyntaxis used in referring grammatical categories in which morphology and syntax are both useful and can be applied in elaborating the words through its characteristics (Crystal, 1980).

In addition, due to evolution, generation to generation language also changes and it affirms that language is dynamic. Neologisms word combination and fixed phrases that appear in the language due to the development are new word, of social life, culture, science and engineering (Sayadi, 2011).To be more specific, neologisms as having recently come into existence lexical or subsisting units that grasp a new wisdom. (Newmark, 2015).

Certainly, many have not noticed it as time passed by so fast and through that, language in much variation changes. Language is vital and open for modification. It changes in some point which a part of language's structure no longer follows the traditional rule or in contrary, it changed at some point whereby it adds unstructured and amorphous style conversation. To sum up, language is open for modification and is a must to conduct an inquiry study to be informed how language affects everyone as a part of the community. 


\section{METHOD}

\subsection{Research Design}

Qualitative research is a well known procedure or strategy that has a vast range of functionality. Traditionally, it is used in the market research but mostly it is used in the social sciences discipline and so on (QSR International, 2015). It is said to be a way of collecting issues, exploring valuable data, considering the possible phenomena behind such, and finally unfolding the mystery through realizing and analyzing the issue of unstructured data (Sparknotes, 2014).

\subsection{Research Subjects}

The subjects of the study were the people whom the researchers would hear speaking the mixed language specifically Cebuano and Tagalog. The qualified subjects of the study were mostly teenagers who engaged themselves in interacting through speaking conyo inside Davao City. The researchers would record the conversation of those subjects to give out or yield essential information needed. In order to determine the subjects some were people that we already know who really spoke the language and some were randomly selected through speaking the language.

\subsection{Research Instrument}

The researchers did mostly gather information through the recordings during the application of our research procedures. Recording different types of conversations in conyo was the only way to get information from the subjects. The researchers only used recording apparatus to record subjects in different locations. However before recording different conversation the researchers filled themselves and enriched with different information and helpful websites that served as a guide and map to gather accurate information from different subjects.

\subsection{Data Gathering Procedures}

The researchers were not allowed to ask for permission or even inform the targeted person or group (speaking in conyo) to record the following conversation. It is the safest way to ensure that the raw information were features of conyo and that it was not deemed biases or sabotaged. The study was accorded through in-depth observation by the researchers whether it was outside or inside the school. Through the observations, the researchers functioned as keen observers and recorded information from random people who were speakers of conyo. Most of the recordings have taken from the public utility jeepneys wherein speakers used it as their means of transportation. In addition, the researchers have recorded as well conversations within the school premises and some were people that we have already known.

\subsection{Trustworthiness of the Study}

In the research, trustworthiness and credibility were needed to test to show validity and reliability. four means of trustworthiness are presented by Lincoln and Guba (1986) as follows:

Transferability exploited proper handling of records of the data obtained from the subjects. For the benefit of the next generation, the research could be used for discussions and gathering information about the nature of Davao conyo as a channel of communication. Confirmability measured the validity of the inquiry's findings were supported by the information gathered. The researchers made sure that the results were gathered from the experiences and inputs coming from the subjects and not from researchers' preferences. Validity studied what was achieved and demonstrated convergence of the information from all sources. The researchers would only acquire the information to the qualified subjects. For validation, all the transcribed information would be checked and corrected by them.

Dependability integrated processes of data obtained and information analysis. It showed the consistency of the results of the study. This research was supported with principle, theory and concepts which made the study reliable.

Credibility evaluated the conceptual of interpretation of the information coming from the subjects' main and original data given. The researchers would give an assurance that the information collected during the course of the interview will be the same as with the information that will be transcribed in the research proper.

\subsection{Scope and Delimitation}

The research was imparted with scope and limitations to elaborate a particular topic of the study. . Through presenting clear scope people would understand more the research. The center of the study is the features of conyo and how to speak in conyo way. In order to reach these objectives the 
researchers used the recordings as a tool to know how the speakers exploit the language. This study only delimits to the speakers of conyo in Davao. Though the recordings was randomly taken but as long as that certain person was speaking the language then the person can be the subject of acquiring such information. However, aside from the recordings the researchers gathered information through in-depth observation from the environment as relying to conyo notion.

\section{RESUlTS AND DisCUSSION}

\subsection{Findings}

\section{Common Conyo Terms}

Looking for the most commonly used Davao Conyo is something that should be given enough time to grasp accurate information. The researchers found out during the course analyzing the data that the most common terms used out of 15 recordings, the same words that were uttered by different people were namely "uy, man, mag, nag, ba, ay, gud and lang". Those words were added in every sentence as they converse.

For instance:

“Asan man tayo mag baba uy?"

“Where are we going to stop?" [PG1 - L1]

"Magkano man pamasahedidto?"

"How much is the fare going there?" [PG1 - L3]

"Nagtanaw kami ng movie ba, horror tapos nag tanongsiyakay papa ba."

“We watched a horror movie then he asked my father." [PG1 - L19]

The above sample presents and proves how the Davao conyo has been uttered and used by diverse people, saying the same common words that are added in every word. Through the help of these words, it would merely emphasize and show the structure and formation being used by the speakers.

There is an idea that is vital in explaining the concept "there are things and ideas as words and some of them are formed". Word formation may consider as the construction of words. There are a lot of ways and techniques to form a new word, it may be word combining or blending to a new name or even shortening the word (Bauer, 1983).

Neologism further explains that there is development that takes place not only through spoken language but also in written words that presents the daily usage of words. That's the reason why few neologisms have occurred yet have not been stored or saved in a lexicon or a dictionary.

Pertaining to the words used by the speakers of Davaoconyo it definitely presents that in order to be considered as conyo it must have its own structure like combining, shortening and even blending words. As stated in one of the commandments in conyo which is "Thou shall make gamitmag+pandiwa" (Anonymous, 2012). For an instance,

\section{"Dapatdiliikaw mag ingana."}

“Do not be like that." [PG 4- L13]

Moreover, another conyomandment is "Thou shall make kalat "oy", "ba","gud" and "man" in your pangungusap"(Anonymous, 2012). For example,

\section{“Ginastalkkogud din sya before beshpero di konaman din sya crush oypara man syangbayotoy." \\ "I'm stalking him as well yet he is not my crush anymore." [PG 2-L7-L8]}

This would mean that through following this particular commandments Davao conyo will be formed and would likely introduce new words in the community. Even if somehow it distorts the existing words usually used by people, the rules given are to retain the conyo notion. Due to the massive existence of technology language has been expanded and has lead to procreation (Tuclaud,2014).

\section{Morpho Syntactic Features of Conyo}

Structures and features of every sentence are important as ordinary people and students would tend to communicate with each other. Inside the classroom, in order for the teacher and students to communicate well, they have to use correct structures of English language to understand each other. Outside the school, though students and other ordinary people do not speak in foreign language but 
still when using their native language such as Cebuano, they have to abide the rules and structure of every sentence structure to transfer the information and message said by the speaker itself. Hence, language structure is vital in every man's means of communication.

A new trend of language is now sprouting all over the city, not only inside the school but it dominates and encourages some to speak its way. In connection with this, the researchers have come up with an idea that the language being studied has also features and structures as closely related to the correct sentence pattern. Though different speakers engage themselves in conyo speaking in a different way, still its characteristics abide grammar structure.

\section{Morphology}

\section{Affixations: Terms Used in Davao Conyo}

Magbaba (to stop), magkano (how much), malinaw(clear), nagbasa (read), nagtan-aw (watch), kahugaw (dirty), ginastalk (stalk), patingin (look) nihubag (swollen), masunog (burn), mupalit (buy), nagtsinelas (wearing slipper), paglinis (to clean), maging'ana (be like that), Makaano (having), nag panic (panic), Gisagot (answer), ngtanong (asking), nagatuo (believe)

\section{Syntax}

Word formation is usually formed as followed:

\section{S-V}

Tapossabingmanghudko.

"After that, my sibling said." [PG 2-LN5-6]

(Taken from the jeepney)

\section{S-V-O}

Butakalangjud .

"You are just blind." [PG 1-LN15]

(Recorded within a particular mall)

Imagine, nakagatakongiro.

"Imagine, I was bit by a dog" [PG 5-LN3]

(Recorded within the classroom)

Hindi akonagatuong HIV.

"I don't believe in HIV." [PG 5-LN2](Recorded within the classroom)

\section{$\mathbf{S}+\mathbf{V}+\mathbf{I O}+\mathbf{D O}$}

Ginastalkkogudyung crush mosa FB.

"I'm stalking your crush in the facebook."

[PG 12-LN12]

(Recorded inside the jeepney)

The occurence of the word formation of conyo is somehow due to the commandment in which it is called conyommandments. "Thou shall make gamitmag+pandiwa" this particular rule is the key why the set of words mentioned above are formed. For an example, the word "maging' ana" yet to be more specific it can be shown like this, mag + ing'ana. It can be seen that ing' ana is the pandiwa and it is just connected to mag that can be considered as the affix.

However, some of the words are formed through combining Cebuano and Tagalog just to bare with the conyo notion. Particularly, Gisagot (answered), this word is derived from gi which is a Cebuano and sagot which is a Tagalog. Though it quite distorts the real word formation of both languages people cannot deny the fact that conyo is a phenomena that is inevitable to speak with.

In pertaining to its structure, conyo has this kind of confusing the mind of the people. It is because if conyo would not only be translated into English it tends to present the sentence wrongly. For an instance, the sentence "Imagine, nakagatakongiro" (Imagine, I was bit by a dog), this sentence shows with the neglection of the word imagine this would mean that the verb becomes the subject. Cebuano is predicated (Tariman, 2009). Cebuano sometimes begins with a verb not with a subject. Through looking to the example given, $\mathrm{V}-\mathrm{S}-\mathrm{O}$ pattern is formed instead of S-V-O in accordance to English structure. 
Combining of words is definitely referring to morphology. Morphology is an important subset of linguistics. It would likely to illustrate the structures of words and patterns of the formation of the words in a specific language. it explains the relationship of the form and the meaning of morphological expressions. Moreover, it expounds the integration of the units in morphology (Hamawand, 2011 as cited by Nordquist, 2015)

Morphology is dealing with morphemes. A morpheme is the smallest unit of function of a language. However, bound morphemes are oftenly used by the means of affixation. Affixation is adding prefixes, suffixes and infixes to a root word to form a word (McCarthy, 2011).

In addition, syntax is an important aspect of the formation of words in conyo. It merely emphasize the chronology of the words in giving credits to grammar. There are certain patterns that can be used in forming words. Basically, S+V+O or (Subject + Verb + Object), S+V+IO+DO or (Subject + Verb + Indirect Object + Direct object) are usually used. The rules are said to be the guide inorder to become efficient in communicating. Syntax gives power to the words in which it connects each other in an order to hold a meaning (Burgess, 1968 as cited by Nordquist, 2015).

Through dissecting morphology and syntax first, it somehow enlightens the connectivity of Morphosynatctic theory to them. Morphosyntax is a category that refers to grammar wherein morphology and syntax are being used to expound the characteristics of a sentence. The main concern of morphology is the formation of words but also through it the meaning of the sentence may vary or may be changed (Crystal, 1980).

\section{How Conyo Affects Social and Academic Life of Conyo Speaker}

In today's generation there are various aspects to influence each other. The domination may come through interacting diverse people or it has always been practiced by the community you used to grow up with. However, this research will present the elements how the social and academic life of the conyo speakers been affected by the said language.

The researchers found out that through using the language it may give the speakers such prestige and power in which these things plays an important into the speakers' lives. Moreover, the said language was considered as their key of having high status in their life. As for this, the social life of the speakers have been widely affected by conyo due to the fact that the speakers used it as a measurement of what status and class where a person was in.

Conyo has been exploited for many years as a common language used by the middle and upper classes, the well educated people and urbanized Filipinos to deviate themselves from other people (Bautista,2004 as cited by Garvida, 2013).

In addition, the researchers have come up to an idea that a speaker may have the capacity to speak the language due to the environment the speaker has been into.

For instance:

“Girl, hindi man akomakasabaysaiyo girl, maggawa man akong resume.”

“Girl, I can't be with you, I will make a resume.” [PG -5, L-8]

The behaviorist theory gives credence that a child may learn an oral language through the influence of another human being by a process of imitation, giving rewards and practice. People around the child may be great models that provide the urge to speak the language (Cooter\&Reutzel, 2004 as cited by Waris, 2015).

Another factor that influences a speaker to adopt such notion is code switching. It explained as the execution of choosing or adapting elements in linguistics to conceptualize interaction in conversing. As for this, it may connect to the practices of local discourse, such as turn selection or diverse structure of bracketing, or it may gather important data beyond the present exchange that involves the knowledge of the community and the identities of distinct people (Nilep, 2006).

The researchers have observed that people used to code switch through using conyo in expressing their ideas. In relation with the academic life of the speakers they tend to speak the said language as a means of explaining their thoughts. The speakers motivate themselves to express what they have in mind inorder to fulfill their goals and get high grades that they wanted. Motivation is one of the key to attain success in life and participation is essential to every learner (San Jose,2012). The researchers 
found out as attending a class in Filipino subject that some students really employ the language for them to expound further what they have in their minds. It is easier for them to converse with conyo as it both use Tagalog and Cebuano unlike speaking in straight Filipino. For instance:

"Marami sa mga tao ngayon katulad na lang ng mga nasa pulitika yang dahil sa ano, mga tao ngayon sa pulitika kanya kanya man talaga sila ng idea."

“A lot of people who are affiliated to politics have their own kinds of ideas." [PG -5, L-7] (Recorded inside the classroom)

"Ang wastong salita ay kailangan gamitin upang magbuo ng salita habang nagstudy."

"The correct choice of words is needed to construct a word while studying." [PG 5-L13-14] (Recorded inside the classroom)

The term code-switching is as well utilized in the field of linguistics as an external factor. The term is used to describe styles in literature that involves the components from greater than one language. In the usual usage of code-switching it is merely sometimes used to affirm the relativity of the stable mixtures of two languages informally. In pertaining to its function in sociolinguistic study, the term code-switching is sometimes used to refer to switching among dialects, styles or registers as moving from less formal to more formal situation.

The assumption of the teachers, linguistics and researchers in code switching can be refer-red that in language learning it may not be considered as a blockage nor a defiance. It was significantly found that students have the tendency to switch from particular language to another as engaging themselves the medium of instruction generally (Bista, 2010).

\section{Conclusion}

\subsection{Concluding Remarks}

The research has been conducted well within the random speakers of conyo. Through the recordings gathered, it helps the researchers to be aware of what really the conyo speakers are into. The people are exploiting diverse languages and dialects yet conyo had caught the eye of the people due to its span-new features. This is one of the reasons why conyo notion has already been spread out throughout the city.

There are factors that have been considered within the research. These factors are the tools of conyo speakers in having the urge to speak the language. Conyo speakers have this so-called conyommandments that serve as the guide of the speakers to retain the notion. The said set of conyommandment is an instrument to converse in conyo way and the passage to transfer messages.

Moreover, the environment they are involved with has a great influenced in speaking the conyo language. The people around them who have a big impact into their lives are one of the aspects why they have the drive to use the language. Another factor is unconsciously uttering the language due to the need of expressing what they want to convey.

These factors have help the researches to build such knowledge in knowing the pillars of conyo language and its speakers. The fact that people are always hearing this phenomenon without knowing the real essence of it. Through the factors that have been known people would not tend to be ignorant and discriminate the speakers of conyo.

\subsection{Implications for Practice}

It was found out that Davao conyo has its own structure and pattern of saying each word uttered, this study being conducted by the researchers is an aid to inform the readers and other researchers about the uniqueness of Davao conyo. Through this research conducted, it aims to help, guide and provide additional information and input to the next batch or generations of $A B$ English students who will be interested to further study topics related to Davao Conyo.

This study is beneficial specially to English major students due to the fact that the study itself concentrates on language. Though the main purpose of the study is to study Davao conyo yet aims to discuss and share information about the language itself here inside the city - Davao.

As future linguists this study conducted by the researchers envisions to share knowledge and learnings. It is basically a study that provides information, results and discussions helpful.

In general, the researchers found this study to be helpful and informative in a way that it solved some questions, confusions and problems related to Davao conyo. It also help the researchers understand 
other people's way of communication through accepting diversity in differences. The research guided the researchers to be open minded on how to avoid discrimination amongst speakers of Davao conyo. Finally, it opened the eyes of the researchers and learned to appreciate the uniqueness of Davao conyo

\section{REFERENCES}

Bauer, L. (1983). English Word-formation. Cambridge: University of Cambridge Press.

Bista, K. (2010). Factors of code switching among bilingual English students in the university classroom: a survey. Retrieved July 10, 2015 from http://www.espworld.com/Articles_29/ Factors.pdf

Crystal, D. (1980). A First Dictionary of linguistics and Phonetics. Colorado: Westview Press Boulder.

Fenton, B., \& Mazulewicz, J. (2008). Trustworthiness. Retrieved June 25, 2015 from http://www. omnivise.com/research/trustworthiness.htm.

Garvida, M. M. (2013). Conyo talk: the affirmation of hybrid indentity and power in contemporary philippine discourse. Lingue e Linguaggi, 8 (24) Retrieved November 12, 2014 from http:// sibaese.unisalento.it/index.php/linguelinguaggi/article/viewFile/12641/11252

Guba, E. (1981). Criteria for assessing the trustworthiness of naturalistic inquiries. Rerieved June 20, 2015 from http://www.nova.edu/ssss/QR/QR13-4/baxter.

Krefting, L. (1991). Rigor in qualitative research: the assessment of trustworthiness. March 1991, Volume 45, Number 3.

Leininger, M.M. (1985). Nature, rationale and importance of qualitative research methods in nursing (Ed.), Qualitative research methods. New York. Retrieved June 24, 2015 from http://www.portal. limkokwing.net/.../rigor/.net.

Lincoln, Y.S., \&Guba, E.G. (1986). But is it rigorous? trustworthiness and authenticity in naturalistic evaluation. New directions for program evalution, 1986(30), 73-84.

McCarthy, C. (2011). Morphology: how words are form?. Retrieved June 20, 2015 from http://popularlinguisticsonline.org/2011/01/morphology-how-words-are-formed/

Newmark, P. (2015). Neologism Retrieved June 22, 2015 from http://www.scribd.com/doc/ 24781934/Neologism\#scribd

Nilep, C. (2006). Code switching in sociocultural linguistics.Colorado Research in Linguistics. Vol. 19. Boulder: University of Colorado. Retrieved July 12, 2015 from http://www.colorado.edu/l ing/CRIL/Volume19_Issue1/paper_NILEP.pdf?q=sociocultural

San Jose, A. E. (2012). Linguistics Experiences of Adult Dyslexic Learners.UIC Research Journals, $18(1)$

Sparknotes. (2014). Language and cognition. Retrieved December 17, 2014 from http://www. sparknotes.com/psychology/psych101/languageandcognition/section2.rhtml

Tuclaud, Joemar Ray V. (2014). Sunday essays: melting dialects of davao.

Retrieved November 10, 2014 from http://www.sunstar.com.ph/weekend-davao/2014/02/08/sundayessays-melting-dialects-davao-327358

QSR International. (2014). What is qualitative research. Retrieved December 17, 2014 from http://www.qsrinternational.com/what-is-qualitative-research.aspx

Waris, M. (2015).Behaviorist theory. Retrieved June 12, 2015 from http://www.academia.edu/ 4456398/Behaviorist_theory_on_language_acquisition. 